\title{
KEMAMPUAN KELUARGA MENURUNKAN BEBAN KELUARGA DALAM MERAWAT PASIEN SKIZOFRENIA
}

\author{
Family's Ability to Reduce The Family's Burden in Care of Schizoprenia \\ Patients
}

\author{
Eriyono Budi Wijoyo ${ }^{1}$, Siti Nopiyanah ${ }^{2}$, Annisaa Fitrah Umara ${ }^{3}$ \\ ${ }^{1}$ Prodi Pendidikan Profesi Ners, Fakultas Ilmu Kesehatan, Universitas Muhammadiyah \\ Tangerang, Indonesia \\ ${ }^{2}$ Prodi Pendidikan Profesi Ners, Fakultas Ilmu Kesehatan, Universitas Muhammadiyah \\ Tangerang, Indonesia \\ ${ }^{3}$ Prodi Pendidikan Profesi Ners, Fakultas Ilmu Kesehatan, Universitas Muhammadiyah \\ Tangerang, Indonesia
}

Korespondensi: Siti Nopiyanah dannopiyanah01@gmail.com

\begin{abstract}
ABSTRAK
Latar Belakang: Skizofrenia merupakan gangguan yang terjadi dalam jangka panjang dapat mempengaruhi proses pikir kemampuan perawatan yang tidak baik menjadi salah satu faktor yang mempengaruhi beban keluarga yang semakin berat. Tujuan Penelitian: mengetahui hubungan antara kemampuan keluarga dengan beban keluarga dalam merawat pasien skizofrenia Di Puskesmas Kedaung Wetan Kota Tangerang. Metedologi: Menggunakan desain deskriptip korelasi dengan rancangan Cross Sectional. Pengambilan sampel dengan metode Purposive Sampling, sebanyak 30 orang. Instrument penelitian ini menggunakan kuesionel kemampuan keluarga dan kuesioner Burden Assessment Schedule (BAS) dengan uji yang digunakan pada penelitian ini menggunakan uji Chi Square. Hasil: Terdapat responden yang memiliki kemampuan perawatan baik sebanyak 14 responden $(46,7 \% \%)$ dengan beban ringan, 16 responden $(46,7 \%)$ yang memiliki kemampuan perawatan tidak baik dengan beban berat. Dengan uji ini didapatkan nilai P Value 0,000 dengan nilai signifikan $\leq 0,05$ bahwa terdapat hubungan yang signifikan antara kemampuan keluarga dengan beban keluarga merawat pasien skizofrenia di Puskesmas Kedaung Wetan Kota Tangerang. Kesimpulan: Terdapat hubungan yang signifikan antara kemampuan keluarga dengan beban keluarga merawat pasien skizofrenia di Puskesmas Kedaung Wetan Kota Tangerang.
\end{abstract}

Kata Kunci: Keluarga Pasien Skizofrenia; Kemampuan Keluarga; Beban Keluarga

Background: $A B S T R A C T$

ABSTRACT

Schizophrenia is a disorder that occurs in the long term and can affect the thought process of poor treatment ability to become one of the factors that affect the increasingly heavy family burden. Research Objectives: This study aims to determine the relationship between family ability and family burden in caring for schizophrenic patients at the Kedaung Wetan Public Health Center, Tangerang City. Methodology: The method in this study uses a descriptive correlation design with a Cross-Sectional design. The population of this study was families who had schizophrenia patients who visited the Kedaung Wetan Public Health Center, 
Tangerang City. Sampling in this study by purposive sampling method, as many as 30 people. The research instrument used a family ability questionnaire and a Burden Assessment Schedule (BAS) questionnaire with the test used in this study using the Chi-Square test. Result: The results in the study some respondents have good maintenance skills as many as 14 respondents (46.7\%\%) with light loads, 16 respondents (46.7\%) have poor maintenance skills with heavy loads. With this test, it was obtained a P-Value of 0.000 with a significant value of 0.05 that there was a significant relationship between the ability of the family and the burden of the family caring for schizophrenia patients at the Kedaung Wetan Public Health Center, Tangerang City. Conclusions: That there was a significant relationship between the ability of the family and the burden of the family caring for schizophrenia patients at the Kedaung Wetan Public Health Center, Tangerang City.

Keywords: Family of Schizophrenic Patients; Family Ability; Family Burden.

\section{PENDAHULUAN}

Skizofrenia merupakan suatu masalah kesehatan yang masih penting untuk diperhatikan. Secara umum tingkat kejadian skizofrenia memiliki prevalensi yang berbedabeda. Menurut Data World Health Organization (2016) mendapatkan data bahwa sekitar 21 juta terkena skizofrenia. Berdasarkan data world Health Organization (2016) masalah jiwa mencapai $13 \%$ dari penyakit secara keseluruhan, kemungkinan berkembang menjadi $25 \%$ di tahun 2030.

Menurut KemenKes RI (2018), gangguan jiwa berat seperti skizofrenia mencapai sekitar 400.000 orang. Secara umum ada peningkatan proporsi gangguan jiwa cukup signifikan jika dibandingkan dengan Riskesdas 2013, naik dari $1,7 \%$ menjadi $7 \%$ orang dengan gangguan jiwa (KemenKes RI, 2018). Menurut DinKes Banten (2015), salah satu provinsi di Indonesia dengan prevalensu skizofrenia yang tinggi yaitu provinsi Banten, sebanyak 6\% menyebar di Kabupaten dan Kota. Data di wilayah Banten menunjukkan prevalensi gangguan jiwa mencapai 535.500 jiwa dan 11 ribu jiwa diantaranya mengalami gangguan jiwa berat dan paling banyak daerah Kota Tangeranf mencapai 5\% dari 2 juta penduduk (DinKes Banten, 2015).

Menurut DinKes Banten (2015), mengemukakan data bahwa terdapat $14,3 \%$ diantaranya atau sekitar 57.000 orang pernah atau sedang dipasung, angka pemasungan didesa adalah sebesar 18,2 angka ini lebih tinggi jika dibandingkan dengan angka perkotaan sebesar $10,7 \%$. Berdasarkan jumlah tersebut ternyata kunjungan pelayanan kesehatan jiwa sebanyak 3.306 kasus pada tahun 2017, skizofrenia menduduki peringkat pertama sebanyak 2328 kasus dipelayanan kesehatan berdasarkkan diagnose. Namun jumlah pelayanan kesehatan jiwa yang dirujuk kerumah sakit sebanyak 726 kasus (DinKes Kabupaten Tangerang, 2017). Namun, berdasarkan DinKes Kota Tangerang (2018), bahwasanya kunjungan pasien gangguan jiwa dibalai kesehatan sebanyak 610 kasus. 
Tingginya angka pasien dengan skizofrenia memerlukan penanganan yang optimal agar kualitas hidup pasien dengan skizofrenia menjadi lebih baik. Pasien skizofrenia membutuhkan dukungan keluarga yang mampu memberikan perawatan secara keseluruhan. Selaian itu keluarga sebagai sistem pendukung utama sering mengalami beban yang tidak ringan dalam memberikan perawatan selama pasien dirawat di rumah sakit maupun setelah kembali kerumah (Suryaningrum, 2013). Keluarga memiliki tanggung jawab untuk merawat, namun dalam pelaksanaanya menyebabkan beban bagi keluarganya (Nuraenah, et.al, 2012). Oleh sebab itu, keluarga merasakan beban yang sangat berat dalam merawat anggota keluarga yang mengalami gangguan jiwa (Agiananda, 2006).

Berbagai penelitian menunjukkan keluarga mengalami beban yang berat dalam merawat pasien skizofrenia. Menurut Sulastri (2018), menerangkan bahwa dampak dari beban yang dirasakan keluarga akan mempengaruhi kemampuan keluarga dalam merawat pasien, sebab hampir semua keluarga menganggap bahwa pasien hanya menjadi beban keluarga karena ketidakmampuan dalam merawat pasien. Beban yang dirasakan keluarga ialah psikososial. Berdasarkan penelitian yang dilakukan oleh Suryaningrum (2013), menunjukkan bahwa terdapat $17,5 \%$ keluarga yang memiliki beban berat.

Selain itu, penelitian Sulastri (2018), mengatakan bahwa terdapat 90\% keluarga yang terbebani dalam hal biaya pengobatan, waktu untuk merawat, malu memiliki anggota keluarga gangguan jiwa, terganggu dalam bekerja, sehingga berkurangnya produktivitas untuk mencari nafkah. Penelitiah serupa yang dilakukan oleh Gurdiansyah (2018), menyatakan bahwa ada $56,3 \%$ keluarga yang melaporkan masalah beban keluarga yang berat. Ada berbagai yang mempengaruhi beban keluarga dalam merawat pasien skizofrenia. Menurut Syafwani (2012), faktor yang berhubungan dengan beban keluarga ialah beban perawatan dan beban psikososial adalah pengetahuan keluarga, pendidikan keluarga dan kemampuan keluarga.

Namun menurut Nuraenah, et.al (2012) berpendapat bahwa salah satu peran dan fungsi keluarga ialah memberikan fungsi afektif untuk pemenuhan kebutuhan psikososial anggota keluarganya dalam memberikan kasih sayang sehingga dukungan berupa sikap dan tindakan penerimaan keluarga dalam, merawat. Berdasarkan penelitian hasil tersebut diperkuat dengan pernyataan Urizar, et.al (2011) bahwa lebih dari 2 tahun atau semakin lama keluarga merawat pasien dengan skizofrenia semakin berat bebannya, sehingga keluarga memiliki sikap yang negative terhadap pasien dan kelainannya. Beberapa penelitian terdahulu menunjukkan bahwa adanya hubungan antara kemampuan keluarga dengan beban keluarga dalam merawat pasien skizofrenia.

\section{TUJUAN PENELITIAN}

Tujuan dalam penelitian ini yaitu mengetahui hubungan antara kemampuan keluarga dengan beban keluarga dalam merawat pasien gangguan jiwa. 


\section{METODE PENELITIAN}

Penelitian ini menggunakan jenis penelitian kuantitatif dengan desain cross sectional. Metode ini mengkaji atau melihat hubungan sesuatu variabel tertentu terhadap variabel lainnya. Sesuai dengan tujuan dari metode penelitian ini, peneliti ingin mengidentifikasi dan mengetahui ada tidaknya hubungan sikap keluarga dengan beban keluarga merawat pasien skizofrenia.

Tempat penelitian ini dilakukan di lingkungan Puskesmas Kedaung Wetan Kota Tangerang. Pelaksanaan penelitian dilakukan pada bulan Maret-Juni 2020. Jumlah sampel pada penelitian ini adalah 30 kunjungan keluarga yang memiliki pasien skizofrenia. Teknik pengambilan sampel yang digunakan dalam penelitian ini adalah menggunakan teknik Purposive Sampling. Instrumen penelitian menggunakan 3 instrumen yaitu kuisioner demografi, kuisioner kemampuan keluarga dan kuisioner beban keluarga. Analisa data pada penelitian ini meliputi Analisa univariat dengan distribusi dan frekwensi lalu Analisa bivariat dengan uji chi square.

\section{HASIL PENELITIAN}

Pada penelitian ini akan menjelaskan data penelitian "Hubungan antara Kemampuan Keluarga Dengan Beban Keluarga dalam Merawat Paisen Skizofrenia Di Puskesmas Kedaung Wetan Kota Tangerang". Penelitian dilakukan pada bulan Juni 2020 Di Puskesmas Kedaung Wetan Kota Tangerang. Proses pengumpulan data menggunakan instrumen berupa kuesioner yang diberikan kepada 30 responden. Kuesioner yang digunakan peneliti adalah kuesioner kemampuan keluarga dan beban keluarga merawat pasien skizofrenia yang sudah dilakukan uji validitas dan reabilitas oleh peneliti.

Selanjutnya penelitian ini dianalisa dengan analisis Univariat dan Bivariat dengan menggunakan program komputer. Hasil analisis data dimulai dari analisa univariat yaitu mengetahui distribusi frekuensi yang meliputi data demografi yaitu: usia, jenis kelamin, suku, pendidikan, pekerjaan, lamanya merawat pasien, serta gambaran kemampuan keluarga dengan beban keluarga merawat pasien skizofrenia. Pada analisis Bivariat peneliti ingin mengidentifikasikan apakah ada hubungan kemampuan keluarga dengan beban keluarga merawat pasien skizofrenia di Puskesmas Kedaung Wetan Kota Tangerang. Pada penelitian ini menggunakan uji normalitas untuk mengetahui distribusi pada kuesioner kemampuan keluarga dan beban keluarga di wilayah Puskesmas Kedaung Wetan Kota Tangerang. Menunjukkan adanya distribusi normal atau tidak normal serta menggunakan hasil ukur mean atau median. Uji normalitas yang di gunakan dalam analisis data penelitian ini berdasarkan pada nilai skewness dengan standar errornya. Jika menghasilkan angka $\leq 2$, maka distribusinya normal sehingga hasil ukur yang digunakan adalah nilai mean. Selain itu, jika menghasilkan $\geq 2$, maka distribusinya tidak normal. Maka hasil ukur yang digunakan adalah nilai median (Dahlan, 2014). Gambaran hasil univariat dapat dilihat pada table dibawah ini. 
Tabel 1. Distribusi Puskesmas Kedaung Wetan Kota Tangerang $(\mathrm{N}=30)$

\begin{tabular}{ccc}
\hline Variabel & $\mathrm{N}$ & $\begin{array}{c}\text { Presentase } \\
(\%)\end{array}$ \\
\hline 20-30 tahun & 2 & 6,7 \\
$31-40$ tahun & 15 & 50,0 \\
$41-50$ tahun & 9 & 30,0 \\
51-60 tahun & 4 & 13,3 \\
Total & 30 & 100 \\
\hline
\end{tabular}

Berdasarkan tabel 1 menunjukkan bahwa karakteristik usia dari 30 responden yang diteliti di Puskesmas Kedaung Wetan Kota Tangerang, berdasarkan mayoritas usia yang paling tinggi sebanyak 15 responden $(50,0 \%)$, usia 41-50 tahun sebanyak 9 responden $(30,0 \%)$, usia 51-60 tahun sebanyak 4 responden $(13,3 \%)$, usia $20-30$ sebanyak 2 responden $(6,7 \%)$.

Tabel 2. Distribusi Frekuensi

Berdasarkan Jenis Kelmain di Wilayah Puskesmas Kedaung Wetan Kota Tangerang $(\mathrm{N}=30)$

\begin{tabular}{|c|c|c|}
\hline Variabel & $\mathrm{N}$ & Presentase (\%) \\
\hline Laki - Laki & 11 & 36,7 \\
\hline Perempuan & 19 & 63,3 \\
\hline Total & 30 & 100 \\
\hline
\end{tabular}
menunjukkan bahwa karakteristik Jenis kelamin 11 responden $(36,7 \%)$, perempuan sebanyak 19 responden $(63,3 \%)$.

Tabel 3. Distribusi Frekuensi

Berdasarkan Suku Di Wilayah Puskesmas Kedaung Wetan Kota Tangerang $(\mathrm{N}=30)$

\begin{tabular}{ccc}
\hline Variabel & N & $\begin{array}{c}\text { Presentase } \\
(\%)\end{array}$ \\
\hline Jawa & 6 & 20,0 \\
Sunda & 19 & 63,3 \\
Betawi & 4 & 13,3 \\
Lain-Lain & 1 & 3,3 \\
Total & 30 & 100 \\
\hline
\end{tabular}

Berdasarkan tabel 3 menunjukkan bahwa karakteristik suku sunda sebanyak 19 suku $(63,3 \%)$, suku jawa sebanyak 6 suku $(20,0 \%)$, suku Betawi sebanyak 4 suku (13,3\%), Lain-lain sebanyak 1 ( $3,3 \%)$.

Tabel 4. Distribusi Frekuensi Berdasarkan Tingkat Pendidikan Di Wilayah Puskesmas Kedaung Wetan Kota Tangerang $(\mathrm{N}=30)$

\begin{tabular}{ccc}
\hline Variabel & N & Persentase (\%) \\
\hline Tidak Sekolah & 3 & 10,0 \\
SD & 15 & 50,0 \\
SMP & 5 & 16,7 \\
SMA & 5 & 16,7 \\
Akademi/S1 & 2 & 6,7 \\
Total & 30 & 100 \\
\hline
\end{tabular}

\begin{tabular}{|c|c|}
\hline & \\
\hline kan & karakteristik \\
\hline pe & 15 \\
\hline re & 5 \\
\hline res & k 5 \\
\hline res & dak $\mathrm{S}$ \\
\hline /S1 s & (6) \\
\hline
\end{tabular}

Tabel 5. Distribusi Frekuensi Berdasarkan Pekerjaan di Wilayah Puskesmas Kedaung Wetan Kota Tangerang $(\mathrm{N}=30)$

\begin{tabular}{|c|c|c|}
\hline Variabel & $\mathrm{N}$ & Persentase (\%) \\
\hline PNS & 1 & 3.3 \\
\hline Wiraswasta & 10 & 33,3 \\
\hline IRT & 19 & 63,3 \\
\hline Total & 30 & 100 \\
\hline
\end{tabular}
menunjukkan karakteristik status pekerjaan dengan jumlah IRT sebanyak 19 responden $(63,3 \%)$, Wiraswasta sebanyak 10 responden $(63,3 \%)$, PNS sebanyak 1 responden $(3,3 \%)$. 
Eriyono Budi Wijoyo, dkk.: Kemampuan Keluarga Menurunkan Beban Keluarga dalam Merawat Pasien Skizofrenia

Tabel 9. Gambaran Berdasarkan Kemampuan Keluarga dengan Beban Keluarga Merawat Pasien Skizofrenia Di Puskesmas Kedaung Wetan Kota Tangerang Tahun $2020(\mathrm{~N}=30)$

\begin{tabular}{|c|c|c|c|c|c|c|c|c|}
\hline Beban Keluarga & \multicolumn{5}{|c|}{ Kemampuan Keluarga } & Total & Df & $\mathrm{P}$ value \\
\hline & \multicolumn{2}{|c|}{ Tidak Baik } & & \multicolumn{2}{|l|}{ Baik } & & & \\
\hline Beban Berat & 14 & 46,7 & 2 & $6,7 \%$ & 16 & & 1 & 0,000 \\
\hline Beban Ringan & 2 & $6,7 \%$ & 12 & $40,2 \%$ & 14 & & & \\
\hline Total & 16 & $53,3 \%$ & 14 & $46,7 \%$ & 30 & $100 \%$ & & \\
\hline
\end{tabular}

Berdasarkan tabel 09 menunjukkan bahwa responden yang memiliki kemampuan perawatan baik sebanyak 16 responden $(53,3 \% \%)$, terdapat 14 responden $(46,7 \%)$ yang memiliki kemampuan perawatan tidak baik dan 2 responden $(6,7 \%)$ yang memiliki beban ringan. Responden yang memiliki beban berat sebanyak 14 responden $(46,7 \%)$, terdapat 2 responden $(6,7 \%)$ memiliki beban ringan dan sebanyak $12(40,2 \%)$ yang memiliki beban berat.

\section{PEMBAHASAN}

Hasil menunjukkan bahwa proporsi responden karakteristik usia didapatkan hasil distribusi frekuensi keluarga skizofrenia di Puskesmas Kedaung Wetan Kota Tangerang, Juni 2020 ( $\mathrm{N}=30$ ). Menunjukkan bahwa 30 responden didapatkan mayoritas usia 3140 tahun. Sejalan dengan penelitian Suryaningrum (2013) dengan judul hubungan beban keluarga dengan kemampuan keluarga merawat dengan kelompok rata-rata 40-60 tahun. Didukung oleh penelitian Sulastri (2018) bahwasanya hasil analisis usia 40 tahun keatas menunjukkan tanggung jawab dalam merawat pasien skizofrenia dan usia diatas 40 tahun merupakan usia produktif, dimana anggota keluarga sudah bersikap dewasa dalam merawat pasien dan kelainannya.

Hasil penelitian ini menunjukkan bahwa proporsi responden berdasarkan jenis kelamin pada keluarga yang memiliki pasien skizofrenia di Puskesmas Kedaung Wetan Kota Tangerang, Juni 2020, $(\mathrm{N}=30)$. Menunjukkan bahwa responden lebih banyak jenis kelamin perempuan sebanyak 19 (63,3\%). Penelitian ini sejalan dengan Friedman (2010) dimana anggota keluarga khususnya perempuan, lebih memainkan peranan penting dalam merawat pasien sehari-hari. Didukung oleh hasil penelitian Nopiyanti (2016) bahwasanya laki-laki memiliki tingkat kejadian tinggi Namun, menurut penelitian Sulastri (2018) menunjukkan bahwa tidak dapat dipungkiri kepala keluarga merupakan penanggung jawab pada anak-anak dan keluarganya, hal ini menunjukan bahwa tanggung jawab mmerawat umumnya diberikan oleh keluarga. Laki-laki lebih stabil dalam mempertahankan keyakinan maupun perilakunya. Analisa penelitian ini, bahwa laki-laki memiliki kemampuan memecahkan masalah dan motivasi dalam merawat pasien skizofrenia. Sehingga ada perbedaan yang bermakna antara jenis kelamin perempuan dan lakilaki masing-masing memilki kemampuan merawat yang berbeda. 
Hasil penelitian ini memperlihatkan bahwasanya distribusi suku di Puskesmas Kedaung Wetan Kota Tangerang. Juni $2020 \quad(\mathrm{~N}=30)$. Menunjukkan dari 30 responden mayoritas responden suku sunda sebanyak 19 (63,3\%). Hal ini sejalan dengan penelitian yang dilakukan oleh Suryaningrum (2013) menunjukkan bahwa DKI Jakarta yang mayoritas Betawi menunjukkan (20,3\%). Analisa pada penelitian dimana suku sangat mempengaruhi, dengan adanya adat dan kebiasaan yang dianut maysrakat yang akan dijadikan panutan dalam menjalani pengobatan secara ilmiah, serta mempercayakan hal yang mistis untuk sebuah kesembuhan.

$$
\text { Hasil penelitian ini }
$$

memperlihatkan bahwa distribusi frekuensi keluarga yang memiliki pasien skizofrenia di Puskesmas Kedaung Wetan Kota Tangerang, Juni 2020, (N= 30). Menunjukkan dari 30 responden mayoritas $15(50,0 \%)$. Hal ini sejalan dengan penelitian Suryaningrum dan Wardani (2013) mengemukkan bahwa tingkat pendidikan responden mayoritas sekolah. Analisa pada penelitian ini, dimana faktor pendidikan merupakan salah satu yang mempengaruhi tingkat pengetahuan dalam merawat pasien skizofrenia. Karena pendidikan merupakan pengalaman yang berfungsi untuk mengembangkan kemampuan dan kualitas pribadi seseorang, dimana semakin tinggi tingkat pendidikan akan semakin besar kemampuannya untuk memanfaatkan pengetahuannya.

$$
\text { Hasil penelitian ini }
$$

memperlihatkan bahwa distribusi frekuensi keluarga yang memiliki pasien skizofrenia di Puskesmas Kedaung Wetan Kota Tangerang, Juni 2020, (N= 30). Menunjukkan dari 30 responden mayoritas bekerja sebagai ibu rumah tangga (IRT) sebanyak $19 \quad(63,3 \%)$ orang. Hal ini sejalan dengan penelitian
Gurdiyansyah (2018) menunjukkan bahwa keluarga terbebani karena banyaknya anggota keluarga yang ekonomi rendah dimana $24(30 \%)$ dari 80 responden dengan pekerjaaan sebagai buruh.. Hasil analisa penelitian ini dimana pekerjaan mempengaruhi beban finansial keluarga dalam kehidupan sehari-hari baik bio-psiko-spiritual.

Hasil penelitian ini menunjukkan bahwa distribusi frekuensi keluarga yang memiliki pasien skizofrenia di Puskesmas Kedaung Wetan Kota Tangerang. Menunjukkan dari 30 responden mayoritas merawat pasien skizofrenia selama $>10$ tahun sebanyak $(36,7 \%)$ orang. Hasil penelitian Dewi G.K (2017) menunjukkan usia 2-9 tahun dengan hasil $(42,86 \%)$. Hasil analisi pada penelitian ini dimana lamanya merawat mempengaruhi beban keluarga baik perawatan, psikososial maupun finansial. Oleh sebab itu, semakin lama merawat maka semakin berat beban yang dirasakan oleh keluarga.

Dalam penelitian ini kemmapuan keluarga mayoritas kemampuan merawat tidak baik sebanyak 16 (53,3\%). Hal ini sejalan dengan penelitian Urizar, et.al (2011) menunjukkan kemampuan tidak baik yang lebih negative terhadap lingkungan dari pada anggota keluarga lainnya pada pasien skizofrenia. Hasil kemampuan keluarga di puskesmas kedaung wetan kota tangerang ini tidak lepas dari beberapa faktor kemampuan negative ialah dari beban berat yang dirasakan keluarga, sehingga mempengaruhi tingkat keberhasilah dalam merawat pasien skizofrenia.

Dalam penelitian ini beban keluarga mayoritas memiliki beban berat sebanyak $16(53,3 \%)$. Hal ini sejalan dengan penelitian Nuraenah, et.al (2012) bahwasanya dukungan keluarga sangat berpengaruh dalam merespon beban keluarga terutama beban objektif dan 
bagaimana mencari pelayanan

kesehatan-kesehatan jiwa dan cara merawat anggota keluarga dengan riwayat skizofrenia. Kualitas hidup pasien skizofrenia dipengaruhi oleh salah satu faktor kemampuan keluarga merawat apabila beban keluarga yang dirasakan berat maka akan mempengaruhi kegagalan dalam pengobatan pada pasien skizofrenia.

Hubungan kemampuan keluarga dengan beban keluarga dalam merawat pasien skizofrenia Di Puskesmas Kedaung Wetan Kota Tangerang. Hasil penelitian ini menunjukkan bahwa responden yang memiliki kemampuan merawat baik memiliki 14 (46,7\%) orang, sedangkan kemampuan merawat tidak baik sebanyak $16(53,3 \%)$ orang. Namun beban berat sebanyak 16 $(53,3 \%)$, sedangkan beban ringan sebanyak 14 (46,7\%). Sehingga dapat disimpulkan bahwa terdapat 14 responden yang memiliki kemampuan merawat baik dengan beban ringan $46,7 \%$ sedangkan yang memiliki kemampuan merawat tidak baik terdapat 16 responden dengan beban berat 53,3\%.

Hasil uji statistic Chi Square dengan table distribusi $2 \times 2$ menunjukkan nilai $\mathrm{P}$ Value $=0,000$ dengan nilai normal $<$ a $(0,05)$ sehingga Ha diterima bahwa terdapat hubungan antara kemampuan keluarga dengan beban keluarga dalam merawat pasien skizofrenia di puskesmas kedaung wetan kota tangerang. Hasil penelitian ini didukung oleh penelitian Ripangga (2018) menunjukkan anggota keluarga yang berkunjung berobat memiliki beban keluarga sebanyak 47 orang $(58,8 \%)$ sebagian besar keluarga yang memiliki kemampuan tidak baik sebanyak 44 orang (55,5\%). Adapun hubungan signifikan antara kemampuan keluarga dengan kemampuan keluarga merawat pasien skizofrenia dengan nilai $r=0,758$ dan P Value yaitu $0,00<0,01$. Didukung oleh penelitian Urizar et.al (2011) kemampuan memiliki hubungan yang signifikan dengan beban keluarga.

Hal ini sesuai dengan teori kemampuan keluarga yang menyatakan bahwa proses penilaian seorang terhadap suatu objek dapat berupa baik dan tidak baik (Sarlito dan Eko, 2009). Penilaian yang muncul, baik atau tidak baik dipengaruhi oleh informasi sebelumnya, atau pengalaman prinadi individu. Menurut Fontane (2009) mengatakan bahwa beban keluarga ialah distress keluarga dimana dapat menyebabkan meningkatkan stress emosional dan ekonomi dari keluarga, sebagaimana respon keluarga terhadap perawatam pasien skizofrenia yang tidak singkat dalam perawatannya.

Namun, hasil penelitian yang dilakukan oleh Agiananda (2006), yang menunjukkan bahwa keluarga mengalami beban dalam merawat anggota keluarga yang menderita skizofrenia, beban yang dirasakan yaitu beban finansial dalam biaya perawatan beban mental dalam menghadapi perilaku pasien, dan beban sosial terutama menghadapi stigma dari masyarakat tentang anggota keluarganya yang mengalami gangguan jiwa skizofrenia.

Menurut Wardani dan Suryaningrum (2013) Dampak dari beban yang dirasakan keluarga akan mempengaruhi kemampuan keluarga dalam merawat pasien. Jika keluarga terbebani kemungkinan keluarga tidak mampu merawat pasien dengan baik.

Berdasarkan hasil penelitian ini didapatkan bahwa mayoritas responden memiliki kemampuan keluarga dan beban keluarga yang berat dikarenakan bagi pasien skizofrenia membutuhkan waktu perawatan bertahu-tahun, yang dapat menjadikan keluarga mengalami kejenuhan dalam memberikan perawatan pada pasien, sehingga keluarga masih 
kurang dalam hal kognitif, afektif perilaku dimana hal itu sebagai salah satu fungsi dari keluarga. Hal ini dapat diartikan bahwa pasien skizofrenia dalam berprilaku dapat merugikan keluarga dan mempengaruhi kemampuan keluarga dalam merawat. Penelitian ini berpendapat bahwa kemampuan keluarga dan beban keluarga sangat berhubungan, ditandai dengan hasil pada penelitian ini keluarga mengalami kemampuan tidak baik dan beban berat yang cukup tinggi. Sebab, beban yang dirasakan keluarga berupa psikososial dan perawatan dimana keluarga harus memahami setiap kondisi pasien baik berupa subjektif maupun objektif bilamana keluarga sudah memahami hal tersebut maka akan meringankan beban keluarga dalam merawat pasien skizofrenia.

\section{KESIMPULAN}

Berdasarkan hasil penelitian dan pembahasan menggunakan uji statistik Chi Square dengan menggunakan program computer Statistik mengenai hubungan antara kemampuan keluarga dengan beban keluarga dalam merawat pasien skizofrenia di wilayah Puskesmas Kedaung Wetan Kota Tangerang, penelitian ini dilakukan kepada 30 responden dengan menggunakan kuesioner. Dapat disimpulkan sebagai berikut 1) Mayoritas usia terbanyak 3140 tahun; 2) Kategori jenis kelamin lebih banyak perempuan; 3) Mayoritas suku terbanyak di wilayah puskesmas yaitu sunda; 4) Berdasarkan kategori pendidikan mayoritas responden berlatar belakang sekolah dasar (SD) ; 5) Berdasarkan status pekerjaan mayoritas responden sebagai ibu rumah tangga (IRT); 6) Sedangkan berdasarkan lama merawat responden selama $>10$ tahun; 7) Sebagian besar mayoritas responden memiliki kemampuan baik sebanyak 14
(46,7\%); dan 8) Paling banyak memiliki beban berat sebanyak $16(53,3 \%)$.

Penelitian ini bersifat kuantitatif yang diperoleh dari keluarga pasien skizofrenia yang berobat di Puskesmas Kedaung Wetan Kota Tangerang dengan demikian tentu tidak terlepas dari keterbatasan yang dapat dihindarkan yaitu 1) Metode dalam penelitian ini hanya bersifat deskriptif, sehingga terbatas pada analisa hubungan variabel dependen dan independen da 2) pengambilan data dilakukan saat responden rutin berobat, upaya yang dilakukan peneliti untuk mengurangi kemampuan dan beban keluarga pada saat bertatap muka langsung antara responden dan peneliti sehingga pada saat mengevaluasi dapat mengurangi kecemasan responden.

\section{DAFTAR PUSTAKA}

Balitbang Kemenkes RI. (2013). Riset Riset Kesehatan Dasa; RIKESDAS. Jakarta: Balitbang Kemenkes RI.

Dharma, K.K. (2011). Metodologi Penelitian Keperawatan. Trans Info Media. Jakarta

Dinkes Banten (2017). Dinas Kesehatan Banten.

http://www.depkes.go.id/resource s/download/profil/PROFIL_KAB KOTA 2015/3671 Banten Kot

a_Tangerang_2015.pdf. 23 Febuari 2019 (20:19).

Djatmiko. (2005). Penentuan Validitas Dan Reabilitas The Burden Assessment Schedule Versi Bahasa Indonesia Dalam Menilai Beban Perawatan Pada Seseorang Yang Merawat Anggota Keluarganya Yang Menderita Skizofrenia. Tesis Universitas Indonesia. Jakarta

Fontaine, K.L. (2009). Mental Health Nursing sixth Edition, New Jersey: Person Education Inc. 
Fontaine, K.L. (2009). Mental Health Nursing. New Jersey: Pearson Education. Inc

Friedman, M.M, Bowden, O \& Jones, M. (2010). Keluarga: Teori dan Praktek: alih bahasa, Achir Yani S, Hamid (et al) : editor edisi bahasa Inodenesia, Estur Tiar, Es.5.Jakarta: EGC.

Friedman. (2013). Keperawatan Keluarga. Yogyakarta: Gosyen Publishing

Hastono, S.P. (2006). modul pertama: pengolahan data uji instrument. Universitas Indonesia. Jakarta

Hawari, D. (2009). Pendekatan Holistik Pada Gangguan Jiwa Skizofrenia. Jakarta: FK-UI.

Jalail. M. (2006). Faktor-faktor Yang Mempengaruhi Kekambuhan Penderita Skizofrenia di RSJ Prof. Soeroyo Magelang, Skripsi. Tidak dipublikasikan.

Keliat, (2011). Keperawatan kesehatan jiwa komunitas : CMHN (Basic course). Jakarta : EGC

Keliat, B. (2003). Disertai. Pemberdayaan Klien dan Keluarga Dalam Perawatan Klien Skizofrenia dengan Perilaku Kekerasan di Rumah Sakit Jiwa Pusat Bogor. Jakarta

Keliat, B.A (2016). Peran Serta Keluarga dan Perawatan Klien Gangguan Jiwa. Jakarta: EGC.

Keliat, B.A., (2000). Peran serta keluarga dalam perawatan klien gangguan jiwa, Jakarta: EGC.

Keliat, B.A. (2006). Pemberdaya klien dan keluarga dalam merawat klien skizofrenia dengan perilaku kekerasan di Rumah Sakit Jiwa Pusat Bogordengen.

KemenKes RI (2018). Laporan Hasil Riset Kesehatan Dasar (RIKESDAS) 2018. Badan penelitian dan pengembangan. Jakarta. http://www.depkes.go.id/article/p rint/16100700005/peran-

keluarga-dukung-kesehatan-jiwamasyarakat.html. 23 Febuari 2019 (2049).

Kusumawati, Farida \& Hartono, (2010). Buku ajar keperawatan jiwa. Jakarta : Salemba Medika

Notoatmodjo, Soekidjo, (2011). Ilmu kesehatan masyarakat : ilmu \& seni. Jakarta : Rineka Cipta.

Notoatmojo, (2012). Metodologi Penelitian Kesehatan, PT.Rineka Cipta. Jakarta

Nurnaenah, et al. (2012). Hubungan dukungan keluarga dan beban keluarga dalam merawat anggota dengan riwayat perilaku kekerasan di RS jiwa islam kleder Jakarta timur 2012. Jurnal keperawatan jiwa. Volume 2. No. 1 41-50.

Ripangga, F. (2018). Hubungan Beban Keluarga Dengan Sikap Keluarga Dalam Merawat Pasien Skizofrenia Di Poloklinik Rumah Sakit Jiwa Atma Husada Mahakam Samarinda. Skripsi Mahasiswa Program Sarjana Keperawatan Universitas Muhammadiyah Kalimantan Timur. Samarinda.

Sinaga B.R. (2006). Skizofrenia \& Diagnosis Banding. Balai penerbit, fakultas KedokteranUniversitas Indonesia, Jakarta.

Struart. G.W. (2013). Buku Saku Keperawatan Jiwa, Edisi 5.EGC. Jakarta

Stuart, G.W \& Sundeen (1995). Principles and practice of Pshychiatric Nursing.

Stuart.G. (2009). Principles and practice of Phychiatric Nursing. 9th ed. St Louis: Mosby.

Suryaningrum, S dan Wardani, I.Y. (2013). Hubungan Antara Beban Keluarga Dengan Kemampuan 
Keluarga Merawat Pasien

Perilaku Kekerasan Di Poliklinik

Rumah Sakit Marzoeki Mahdi

Bogor. Jurnal Keperawatan Jiwa,

Volume 1, No 2 148-155

Videbeck, S.L (2008). Buku Ajar

Keperawatan Jiwa. Jakarta: EGC.

Videbeck, S.L. (2008). Buku Ajar

Keperawatan Jiwa. Jakarta:EGC.

WHO. (2016). Nations For Mental

Health, Schizophrenia And

Public Health. World Health

Organization.

WHO. (2017). Depression and Other common Mental Disorders.

Global Health Estimates.

Geneva: World Health

Organization.

Yosep, (2013). Keperawatan jiwa, Edisi

4 Jakarta : Fefika Aditama

Yuli \& Kristin. (2017). Hubungan

Pengetahuan Keluarga Tentang

Personal Hyegiene Dengan

Kemampuan Keluarga Merawat

Anggota Keluarga Yang

Mengalami Gangguan Jiwa.

Jurnal Keperawatan. Vol.14.no.2 
Eriyono Budi Wijoyo, dkk.: Kemampuan Keluarga Menurunkan Beban Keluarga dalam Merawat Pasien Skizofrenia 
Nama Penulis: 10pt; Bold; Italic; Cappialize Each Words 